stimulate a surge of research in high-density spinal cord recording and stimulation interfaces, closed-loop control algorithms, implanted wireless systems, and sensory-based training procedures?

Harkema and colleagues achieved a level of functional recovery in a paraplegic patient that remains unprecedented in $\mathrm{SCl}$ medicine. Although these results need to be confirmed in a clinical trial with a statistically sound number of participants, the exceptional results bring new hope in a field that has remained unsatisfying - with limited progress despite decades of research throughout the world. We are entering a new era when the time has come for spinal-cord-injured people to move.

\footnotetext{
*Grégoire Courtine, Rubia van den Brand, Pavel Musienko Experimental Neurorehabilitation Laboratory, Department of Neurology, University of Zurich, Zurich 8008, Switzerland (GC, RvdB, PM); and Motor Physiology Laboratory, Pavlov Institute of Physiology, St Petersburg, Russia (PM) gregoire.courtine@uzh.ch

GC and PM have a patent pending for electrode-array stimulator systems. GC has received funds from the European Community's Seventh Framework Programme (CP-IP 258654, project NeuWALK) for related research. RvdB declares that he has no conflicts of interest.

1 Thuret S, Moon LD, Gage FH. Therapeutic interventions after spinal cord injury. Nat Rev Neurosci 2006; 7: 628-43.
}

2 Dietz V. Ready for human spinal cord repair? Brain 2008; 131: 2240-42.

3 Dietz V, Colombo G, Jensen L. Locomotor activity in spinal man. Lancet 1994; 344: 1260-63.

4 Behrman AL, Harkema SJ. Locomotor training after human spinal cord injury: a series of case studies. Phys Ther 2000; 80: 688-700.

5 Harkema SJ. Plasticity of interneuronal networks of the functionally isolated human spinal cord. Brain Res Rev 2008; 57: 255-64.

6 Capaday C. The special nature of human walking and its neural control. Trends Neurosci 2002; 25: 370-76.

7 Musienko P, van den Brand R, Maerzendorfer O, Larmagnac A, Courtine G. Combinatory electrical and pharmacological neuroprosthetic interfaces to regain motor function after spinal cord injury. IEEE Trans Biomed Eng 2009; 56: $2707-11$.

8 Courtine G, Gerasimenko Y, van den Brand R, et al. Transformation of nonfunctional spinal circuits into functional states after the loss of brain input. Nat Neurosci 2009; 12: 1333-42.

9 Musienko PE, Zelenin PV, Orlovsky GN, Deliagina TG. Facilitation of postural limb reflexes with epidural stimulation in spinal rabbits. J Neurophysiol 2010; 103: 1080-92.

10 Musienko PE, Bogacheva IN, Gerasimenko YP. Significance of peripheral feedback in the generation of stepping movements during epidural stimulation of the spinal cord. Neurosci Behav Physiol 2007; 37: 181-90.

11 Harkema S, Gerasimenko Y, Hodes J, et al. Effect of epidural stimulation of the lumbosacral spinal cord on voluntary movement, standing, and assisted stepping after motor complete paraplegia: a case study. Lancet 2011; published online May 20. DOI:10.1016/S0140-6736(11)60547-3.

12 van den Brand R, Heustschi J, Friedli L, et al. Neurorehabilitative interventions restore voluntary locomotor activities following severe spinal cord injury. Neuroscience Meeting Planner; San Diego, CA: Society for Neuroscience; Nov 16, 2010: 684.11. http://www.abstractsonline.com/Plan/ ViewAbstract.aspx?sKey=0eca72e6-550f-4aa9-8312-47056d835f71\&cKey= 7065db24-49aa-4024-80d0-93c165dc8808\&mKey=\{E5D5C83F-CE2D4D71-9DD6-FC7231E090FB) (accessed May 13, 2011).

13 Musienko PE, Van den Brand R, Märzendorfer O, et al. Controlling specific locomotor behaviors through multidimensional monoaminergic modulation of spinal circuitries. J Neurosci (in press).

\title{
@ Higher education and health care in Brazil
}

Published Online May 9, 2011 DOI:10.1016/S0140-

6736(11)60326-7

See Series pages 1949 and 1962

See Series Lancet 2011; 377: 1778,1863 , and 1877

See Online/Series DOI:10.1016/S01406736(11)60055-X
Until the mid-20th century, there was no health-care system in Brazil. ${ }^{1}$ Rich patients were treated in private institutions, paying out-of-pocket fees; workers had access to labour-union clinics and hospitals. In urban areas, people who were poor had to seek assistance in overcrowded philanthropic or public institutions that would accept those who were indigent to Brazil. In rural areas, peasants and sharecroppers had to rely on healers or untrained lay caretakers for their health needs. At the peak of the country's redemocratisation, the Constitution of 1988 declared health care as a citizen's right and a duty of the State. ${ }^{2}$ Thereafter the Unified Health System (Sistema Único de Saúde or SUS) was organised with principles of universality, integral care, health promotion, and community participation, with public funds to provide free health care to Brazilian citizens. ${ }^{1}$

The SUS has two main lines of operation: the Family Health Programme provides primary health care in 5295 municipalities, and a network of public or
SUS-contracted clinics and hospitals delivers secondary and tertiary care nationwide. Along with public health interventions, which started in the 1970s, and with more recently implemented social policies related to employment and conditional cash-transfer, the impact of the SUS after 20 years has been positive. ${ }^{13,4}$ Over the past three decades, infant mortality decreased by about $6.3 \%$ a year, and life expectancy increased by 10.6 years. ${ }^{3}$ Mortality due to infectious disease decreased from $23 \%$ of total deaths in 1970 to less than $4 \%$ in 2007. ${ }^{4}$ Despite such achievements, serious problems involving equity, quality, and efficiency need to be acknowledged. Insufficient investment, corruption, and poor management because of governmental bureaucracy are among such problems. The main determinant of low-quality care provided by the SUS network is limited human resources; however, this limitation is qualitative not quantitative.

The health-care workforce of Brazil comprises 1.5 million health professionals registered in professional boards 
(table). The SUS network is the country's major employer: $52 \%$ of nurses, $44 \%$ of physicians, $27 \%$ of dentists, $11 \%$ of pharmacists, and $10 \%$ of psychologists are public employees.-9 ${ }^{7-9}$ Furthermore, 3493 university-level courses for health professions are offered, with 185 medical schools hosting 97994 students. ${ }^{5}$ The ideal SUS workforce-ie, skilled, evidence-oriented, well-trained professionals who are committed to equity in healthdoes not match the profile of the professionals who operate the system. This disparity is partly because of selfselection. The private sector promotes an individualistic ideology in which public service is considered as merely underpaid employment, which offers stability, secondary to private entrepreneurship or jobs in for-profit health enterprises, which are allegedly more rewarding. However, increased understanding of this problem might be found in the dissonance between the SUS's mission and the higher education system. Thus the key issue for health care in Brazil might be the deformation of education-humanistic, professional, and academic-of health personnel.

Similar to the situation in the USA before the Gilman-Flexner reform and to that in continental Europe before the Bologna Process, medicine, dentistry, pharmacy, nursing, psychology, and other health-related professions are all undergraduate degrees in Brazil. ${ }^{11}$ In this system, by going directly into professional courses, young immature students are forced to make crucial career decisions too early in their lives. Several corollaries characterise this system. First, harsh competition for entry to courses of high social prestige (eg, medicine), typically after expensive preparatory courses, makes them monopolies of affluent classes, whose members tend to support individualistic approaches to health care. Second, there is almost no place for other more general studies, which are necessary to promote a broad humanistic view of health-disease care in health professionals. Third, self-contained curricula that are designed for exclusivity tend to be less interdisciplinary and more specialised, thus alienating professional segments from one another and making it difficult to efficiently work in a team.

In 2008, a new university reform was launched in Brazil. Among other measures, a massive investment plan called REUNI is doubling the federal university network in size, allowing for the implementation of interdisciplinary undergraduate courses compatible

\begin{tabular}{|c|c|c|c|c|c|c|}
\hline Health profession & $\begin{array}{l}\text { Schools } \\
\text { and } \\
\text { courses }^{5}\end{array}$ & Students ${ }^{5}$ & $\begin{array}{l}\text { Registered } \\
\text { professionals* }\end{array}$ & $\begin{array}{l}\text { Ratio per } \\
\text { population }\end{array}$ & $\begin{array}{l}\text { At the } \\
\text { public } \\
\text { service } \\
\text { (SUS) }(\%)^{7}\end{array}$ & $\begin{array}{l}\text { Working for } \\
\text { the FHP } \\
(\%)^{8-10}\end{array}$ \\
\hline Medicine & 185 & 97994 & 341562 & $1: 558$ & $44 \cdot 3$ & $4 \cdot 9$ \\
\hline Nursing & 752 & 234070 & 271809 & $1: 701$ & $52 \cdot 5$ & $10 \cdot 9$ \\
\hline Dentistry & 196 & 53586 & 219575 & $1: 868$ & $26 \cdot 9$ & 8.8 \\
\hline Pharmacy & 444 & 99896 & 133762 & $1: 1424$ & $10 \cdot 6$ & $2 \cdot 2$ \\
\hline Psychology & 495 & 124593 & 236100 & $1: 807$ & $10 \cdot 4$ & $2 \cdot 8$ \\
\hline $\begin{array}{l}\text { Other allied } \\
\text { health professions }\end{array}$ & 1421 & 172807 & 295499 & $1: 645$ & $\mathrm{~N} / \mathrm{A}$ & $\mathrm{N} / \mathrm{A}$ \\
\hline \multicolumn{7}{|c|}{$\begin{array}{l}\text { SUS=Sistema Único de Saúde. FHP=Family Health Program. N/A=not available. *Updated 2010. Sources: Brazil Federal } \\
\text { Boards (Conselhos Federais) of health professions (medicine, nursing, dentistry, pharmacy, psychology, nutrition, } \\
\text { physiotherapy, phonoaudiology). }\end{array}$} \\
\hline
\end{tabular}

with the US college system and the European Bologna model. ${ }^{11}$ As a result, tension has emerged among Brazilian universities. The academic establishment, led by traditional faculties, is against reshuffling the ideological basis of higher education and, therefore, tends to refuse innovative course designs. However, for education of the health workforce, the SUS has provoked a strong political demand to replace the reductionist, disease-oriented, hospital-centred, specialisationdriven pattern of professional education by one that is more humanistic, health-oriented, focused on primary health care, and socially committed. In this context, the State, pushed by social movements, has taken the lead over the universities with initiatives such as REUNI and, particularly, the Pro-Saúde-a SUS-based programme to reform higher education for the health workforce. ${ }^{12}$

Although conservative and elitist, universities are not the main source of the problem because the health-education system reflects the health-care model that still prevails in contemporary Brazil, ruled by market-oriented forces and based on medical technology, rather than on solidarity and humane social relations.

\section{Naomar Almeida-Filho}

Instituto de Saúde Coletiva, Universidade Federal da Bahia, Campus Universitário Canela, Salvador, Bahia 40.110-040, Brazil naomarf@ufba.br

I thank Bob Verhine, Maurício Barreto, and Luis Eugênio Portela de Souza for reviewing my Comment and for providing helpful criticism. I have received grant support (grant number 302600/2008-6), payment for lectures, and research support from the Brazilian National Research Council (grant number 302600/2008-6).

1 Paim J, Travassos C, Almeida C, Bahia L, Macinko J. The Brazilian health system: history, advances, and challenges. Lancet 2011; published online May 9. DOI: 10.1016/S0140-6736(11)60054-8. 
2 Brazil. Federative republic of Brazil: 1998 Constitution with 1996 reforms. November, 2008. http://pdba.georgetown.edu/Constitutions/Brazil/ english96.html (accessed March 15, 2011).

3 Victora CG, Aquino EML, do Carmo Leal M, Monteiro CA, Barros FC, Szwarcwald CL. Maternal and child health in Brazil: progress and challenges. Lancet 2011; published online May 9. DOI:10.1016/S0140-6736(11)60138-4.

4 Barreto ML, Teixeira MG, Bastos Fl, Ximenes RAA, Barata RB, Rodrigues LC. Successes and failures in the control of infectious diseases in Brazil: social and environmental context, policies, interventions, and research needs. Lancet 2011; published online May 9. DOI:10.1016/S0140-6736(11)60202-X.

5 Brasilia: Ministério da Educação/Instituto Nacional de Estudos e Pesquisas Educacionais Anísio Teixeira. 2009 higher education census. http://www. inep.gov.br/superior/censosuperior/default.asp (accessed March 15, 2011) (in Portuguese)

6 Brasília: Instituto Brasileiro de Geografia e Estatística. 2010 population census. http://www.censo2010.ibge.gov.br (accessed March 15, 2011) (in Portuguese).

7 Ministério de Saúde. DataSUS. http://tabnet.datasus.gov.br/cgi/tabcgi. exe?cnes/cnv/prid02br.def (accessed Jan 7, 2011) (in Portuguese).

8 Morita MC, Haddad AE, de Araújo ME. Current profile and trends of the Brazilian dentist-surgeon. Maringá: Dental Press International, 2010. http://cfo.org.br/wp-content/uploads/2010/04/PERFIL_CD_BR_web.pdf (accessed Jan 10, 2011) (in Portuguese)
9 Spink MJP, Bernardes JdS, Menegon VSM, Santos L, Gamba AC. The engagement of psychologists in SUS-related health services: subsidies to understand dilemmas of the practice and the challenges of professional education. In: Spink MJP, eds. Psychology in dialogue with the SUS: professional practice and academic production. São Paulo: Casa do Psicólogo, 2007: 53-80. http://www.abepsi.org.br/web/Relatorio pesquisa_ABEP.pdf (accessed March 15, 2011) (in Portuguese)

10 Ministério da Saúde. Secretaria de Atenção à Saúde. http://portal.saude. gov.br/portal/saude/Gestor/area.cfm?id_area=1529 (accessed Jan 8, 2011) (in Portuguese)

11 Santos BdS, Almeida-Filho N. The university of the 21st century: towards a new university. Coimbra: Almedina Press, 2008 http://www boaventura desousasantos.pt/media/A\%20Universidade\%20no\%20Seculo\%20XXI.pdf (accessed March 15, 2011) (in Portuguese).

12 Ministério da Saúde, Ministério da Educação. National programme for reorientation of professional formation in health. 2007. http://prosaude org/rel/pro_saude1.pdf (accessed Jan 11, 2011) (in Portuguese)

\section{Oxford University should stop investing in arms companies}

It will surprise nobody to learn that the wars in Afghanistan and Iraq-so deadly to those who have suffered in them-have reaped enormous profits for arms companies. ${ }^{1}$ What may come as a surprise is that many of the UK's most respected universities-including ours, Oxford-have also cashed in on these wars, by investing (either directly or indirectly) large amounts of their endowment capital in shares in major global arms companies. ${ }^{2}$ Oxford University provides a revealing-but by no means unique-example: requests under the Freedom of Information Act made by Campaign Against the Arms Trade ${ }^{3}$ and our student group ${ }^{4,5}$ have revealed

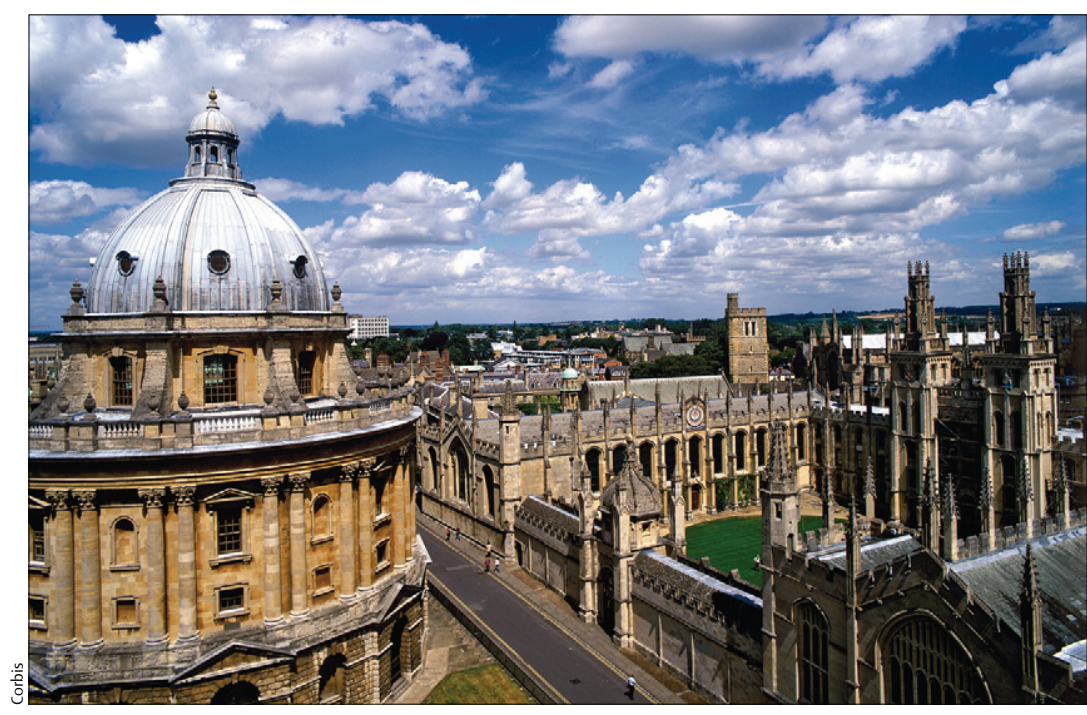

that, between 2008 and 2010, Oxford's endowment and capital funds were investing on average $£ 4.5$ million of their assets (through third-party funds) in BAE Systems, Raytheon, Lockheed Martin, and other UK and US arms manufacturers. For Oxford, as for other universities, the lure of large returns appears to have been too lucrative to resist. Yet at a time when there is an increasing public awareness about the conduct of these and other wars, helped in large part by the WikiLeaks release last year of thousands of US military files, with their evidence of what many would consider to be promiscuous rules of engagement ${ }^{6}$ and indiscriminate killings, ${ }^{7-9}$ universities like Oxford can no longer ignore the ethical implications of their investments.

Take Oxford's holding in Lockheed Martin. In April, 2010, the University held $£ 1.4$ million worth of shares in this US-based company ${ }^{5}$ that makes the Hellfire missile. ${ }^{10}$ The WikiLeaks release records the killing of an Iraqi boy by a Hellfire missile fired at him by a US helicopter while he was collecting firewood. ${ }^{8}$ A Hellfire missile is also seen killing a passer-by as it is launched at a civilian structure at the end of the infamous Collateral murder video released by WikiLeaks, which shows footage from a US helicopter cockpit of innocent civilians gunned down in Baghdad, accompanied by the crew's mocking commentary: "Oh, yeah, look at those dead bastards. Nice." ${ }^{\prime \prime}$ In both cases the helicopters were Apaches, manufactured by Boeing, another company 